\title{
김ouRnal.ru
}

Савицкий B.M.

Самарский гос. сочиально-педагогический университет

Самара, Россия

doi: 10.18411/1j2016-1-14

\section{Влияние жанрово-стилевых характеристикдискурса напорождениевысказывания}

В ХХстолетии в русле трансформационно-порождающей грамматики и близких к ней отраслей генеративистики, направленных на то, чтобы сделать науку о языке точной наукой, была предпринята попытка описать естественный язык как кибернетический автомат,который по строгому алгоритму порождает правильные высказывания на данном языке. Строились планы реализации упомянутого «автомата» в виде компьютерной программы, которая, по замыслу ее создателей, должна была генерировать речь, не отличающуюся от речи человека, при условии, что в ней будет заложено «полное, достаточное и эксплицитное описание всех языковых объектов и правил» [Апресян 1981: 16].

По А.А. Леонтьеву, основу речепорождения составляет «механизм выбора и организации слов» [Леонтьев 1990: 387].Генеративистыполагали, что в ходе порождения речи упомянутые «выбор и организация»происходят сами собой, по правилам, содержащимся в системе языка.Но опыт показывает, что моделирование живой, подлинной человеческой речи заставляет учитывать факторы, выходящие за рамки языковой системы.Порождающие модели такого рода должны содержать не только строгие, но и эвристические алгоритмы, носящие не языковой, а культурно-и социально-семиотический характер.

По М. Халлидею, три фактора порождения речи в своей совокупности образуют коммуникативный регистр: fieldofdiscourse «область (тематика) 
дискурса»; tenorofdiscourse «ролевая диспозиция коммуникативного акта (взаимоотношения его участников)»; modeofdiscourse «модус дискурса (цель и жанрово-лингвистические свойства акта общения)» [Halliday 1978].

По нашим наблюдениям, выбор и организация языковых средств при построении высказываниярегламентируютсявсеми тремя перечисленными факторами(см. нашу работу[Савицкий 2013: 25-111]). Внастоящейстатье описаны лишьжанрово-стилевые характеристики дискурса, входящие в его модус. Они не полностью детерминированы намерением продуцента речи.Иногда он не волен в выборе жанра и стиля; они могут диктоваться параметрами акта общения, в который вовлечен продуцент речи. В этих случаях он вынужден подстраиваться под диктуемые ему условия общения, выбирая те языковые средства, которые предусмотрены требованиями не им избранного жанра и стиля. В таких случаях роль личности говорящего и преследуемых им целей и интересов снижается, и на первый план выдвигаются соображения жанрово-стилевого характера. Субъективные мотивы заменяются объективными правилами общения.

Человек - многогранный объект номинации. Одно и то же лицо можно именовать по-разному; выбор имени лица зависит, в числе прочего, от жанра истиля речевого произведения. Рассмотримэтузависимость. ПриведемпримерыизамериканскихСМИза2006-2007гг. В этих примерах в качестве референта выступает тогдашний президент США Дж. Буш-младший.

AccordingtotheConstitution,

PresidentoftheUnitedStatesisheadoftheExecutivepower«СогласноКонституции, Президент Соединенных

Штатовявляетсяглавойисполнительнойвласти»(жанрнормативногодокумента, стильвысокогогосударственногоофициоза).

PresidentBushisreportedtobebackfromhisEuropeancircuit «Каксообщают, президент БушвернулсяизтурнепоЕвропе» (жанркоммюнике, полуофициальныйстиль). 
Бушпроводитвыходныенаранчо в Техасе» (новостной жанр, более непринужденный стильСМИ).

GeorgeBush'sGulfWarinitiativeshavetoldbadlyonhispublicimage«Политически ешаги Джорджа Буша в связи с войной в заливе плохо сказались на его имидже»(жанр политобзора, полемический стиль).

Oppositionsplashing, "Bush, HandsOffIraq" «Вздымаетсяпротест: “Буш,рукипрочь от Ирака!”» (жанр лозунга, разговорный стиль).

ThisisnotwhatDaddytaughtGeorgiewhenhewasaboy «Этонето, чему папочка[Буш-старший - B.C.] учил Джорджсика, когда тот был еще маленький»(жанр фельетона, фривольный сатирический стиль).

М.Я.Поляков охарактеризовал жанр (в одном из его аспектов) как «определенное количество директив, обусловливающих данный способ сообщений» [Поляков 1986: 301]. По поводустиля Ю.С.Степанов отметил: «Стиль всегда характеризуется принципами отбора и комбинации наличных языковыхсредств» [Степанов 1990: 493]. Как видим, и жанр, и стиль содержат предписания (директивы, принципы), касающиеся порождения речи. В их число входят правила выбора и сочетания имен обозначаемых лиц.

В прессе разных уровней респектабельности принцесса Диана звалась поразному: HerRoyalHighness «Ее королевское высочество», PrincessDiana «Принцесса Диана», thePrincess «Принцесса», Diana (Диана), LadyDi «леди Ди»,theQueenofHearts«царицасердец» / «червоннаядама», theFairLady «Прекрасная леди», thePearloftheCrown «жемчужина Короны» и др. Выбор этого имени определялся в первую очередь модусом дискурса - тем сектором коммуникативного пространства, wherethelanguagecomesin«где в дело вступает язык»[Halliday 1978: 112], или, иными словами, не столько экстралингвистическими факторами, сколько способами использования языка впроцессе общения, а именно жанрово-стилевыми характеристикам дискурса.

К сфере модуса дискурса относится также речевой этикет, 
определяемыйкак «система устойчивых формул общения, применяемых обществом ...соответственно социальным ролям и ролевым позициям [собеседников] относительно друг друга, взаимным отношениям в официальной и неофициальной обстановке» [Формановская 1990: 413]. Исходя из того, что существуют не только формулы, но и правила речевого этикета, следует добавить, что в состав этикета наряду с формулами входят правила их применения, обусловленные социосемиотическими параметрами речевых ситуаций. Исходя из того, что система знаковых единиц и система правил их употребления составляют код, можно утверждать, что речевой этикет - это один из кодов, образующих лингвокультуру. Следует отметить, что выбор языковых единиц (в частности, имен лица) «соответственно социальным ролям, ролевым позициям ... [и]взаимоотношениям [собеседников]» по правилам речевого этикета - это не тоже самое, что их выбор под воздействием факторов «область дискурса» и «ролевая диспозиция».Выбор одного и того же имени может диктоваться разными факторами.

Обратимся для примера к имени doctor. Иногда оно выбирается потому, что нужно объяснить действие лица: The doctor forced his way throught he crowd and knelt beside thein jured man «Врач протиснулся сквозь толпу и опустился на колени перед пострадавшим». Человек поступил так в соответствии со своей позиционной ролью. Выбор имени обусловлен фактором «область дискурса».

В высказывании I sawmydoctorplayingpool«Я видел, как мой докториграл в бильярд» обозначено действие, не относящееся к роли «врач». Выбор имени (my)doctoroбусловлен социальным отношением говорящего с данным лицом («пациент - врач»), то есть фактором «ролевая диспозиция».

Наконец, в таких сочетаниях, как Mr. HolmesandDr. Watson (мистерХолмс идоктор Ватсон), Dr. JekyllandMr. Hyde (доктор Джекилл и мистер Хайд) и т.п.,слово Doctor (Dr.) употреблено исходя из этикетных соображений, как эквивалент слова Mister (Mr.), используемый по отношению к врачу. В этих случаях выбор имени обусловлен фактором «модус дискурса». 
Таким образом, прямое употребление ролевых имен и употребление имен «соответственно ролям и взаимоотношениям» не всегда совпадают. Ролевое имя (например, doctor) может выступать в речи как реляционное имя (имя взаимоотношения) или как этикетное, то есть не в своей прямой функции, но в косвенной соотнесенности с данной ролью. И наоборот, имя, не обозначающее социальной роли прямо, может указывать на нее косвенно. Приведем примеры.

At ten to four this gentleman entered the reception room and asked when His Hon or wouldc ome «Без десяти четыре это тго сподин вошел в приемную испросил, когда придет Его честь» (D. Hammett. TheManNamedSpade).

Имя HisHonor (Его честь), прямо обозначающее не роль, а лишь высокий ранг лица, в этом контексте косвенно указывает на конкретнуюпозиционную роль («судья»). Это не имя роли, но оно использовано «соответственно» роли(данный титул по этикету соответствует, помимо прочих, должности судьи). Эти примеры наглядно иллюстрируют дефиницию Н.И.Формановской.

Иногда речевой этикет требует «смещённого» употребления ролевого имени по отношению к лицу, не исполняющему данную роль. Так, этикетный вопрос гостя Whoistheartist? (Кто художник?) означает не «Кто автор этой картины?», а «Кто в вашей семье интересуется живописью?»[Карасик 1992].

Добавим, что в ряде случаев выборимени лица определяется не одним, а двумя или всеми тремя факторами. Например, встереотипнойформулеI'llgiveevidenceonlyinmylawyer'spresence «Я буду давать показания только в присутствии моего адвоката» характер номинации лица (адвоката) обусловлен:

1)фактором «область дискурса» (поскольку человек упомянут здесь в связи с его профессиональной деятельностью, он именуется по должности);

2) фактором «ролевая диспозиция» (говорящий указывает на вид социального отношения между ним и обозначаемым лицом).

Но так бывает не всегда: если действие не соответствует роли, то фактор «область дискурса» при выборе имени лица не задействуется. Например: 
Isawmylawyerbuyingcheeseatthesupermarketthismorning «Нынчеутромвсупермаркетеявидел, какмойадвокатпокупалсыр».

Хотя действие не соответствует роли, это высказывание нормативно, т.к. характер действия в данном случае неважен для выбора имени. Выбор имени обусловлен здесь только одним фактором - «ролевая диспозиция»: отношение «клиент - адвокат» для говорящего столь значимо, что он называетэтого человека своим адвокатом в любых ситуациях, что бы тот ни делал. Ср.:

Lieutenant,this thing ... will have to be taken up with the general «Лейтенант, этотвопрос ... надообсудитьсгенералом»(S.Heym.ATrueStory).

Оба позиционно-ролевых имени (lieutenant, general) использованы:

1) в связи с профессией именуемых лиц (фактор «область дискурса»);

2) согласно правилам воинского устава (фактор «модус дискурса»).

Однаковвысказывании The General left his daughters more than 300000 poundswhenhedied«Покойный генерал оставил своим дочерям свыше трехсот тысяч фунтов» (A.Christie. DumbWitness) выбор имени лица (thegeneral) обусловлен только одним фактором - речевым этикетом, входящим в модус дискурса. Фактор «область дискурса» здесь не задействован, поскольку названное действие («оставил наследство») не входит в позиционную роль «генерал». Не задействован и фактор «ролевая диспозиция»: по сюжету романа, говорящая (мисс Пибоди) не состояла ни в каких отношениях с покойным.

В клише OurRoyalBrotherhonouredUswith a visit «Наш августейший брат почтил Нас визитом» выбор имени лица обусловлен:

1) фактором «область дискурса» (слово Royal «августейший» указывает на монарший статус именуемого лица, и действие «почтить визитом» входит в эту статусную роль);

2) фактором «ролевая диспозиция» (говорящий, который тоже является монархом, указывает на свое социальное отношение с именуемым лицом);

3) фактором «модус дискурса» (говорящий соблюдает предписания дипломатического протокола). 
Как видим, выбор имени лица в ряде случаевосуществляется под влиянием двух или даже всех трех факторов.

Обратимся к вопросу о соотношении дистрибуции (распределения) имен. Какизвестно, врамках дистрибутивного анализа различаются дополнительноераспределение,контрастивное распределение и свободное варьирование языковых единиц(см.: [Harris 1951]; [Gleason 1966]идр.).

В дополнительномраспределении имена лица находятся тогда, когда они не могут использоваться в одних и тех же контекстах. Например:

The angler (but not *thephilatelist) threw the bait«Рыболов (ноне *филателист) закинулудочку».

Имена «рыболов» и «филателист» могут относиться к одному и тому же лицу, но вряд ли они могут встречаться в одних и тех же окружениях в позиции подлежащего при акциональном глаголе: рыбная ловля и коллекционирование марок характеризуются разными наборамиролевых действий.

Вдругихслучаяхдополнительноераспределениеобусловленожанровостилевымиразличиями:

President of the United States (but not*Georgie) paid an official visit to the UnitedKingdom at the invitation of Her Majesty the Queenof England «ПрезидентСША(ноне *Джорджик) нанесофициальныйвизитвСоединенноеКоролевствопоприглашениюЕе Величества королевы Англии».

Официозный и фривольный жанрово-стилевые форматы не допускают взаимозамены имен лица (если не считать их иронического употребления).

В контрастивномраспределении имена состоят, когда они встречаются водном контексте и при этом различают детали содержания высказываний:

The Department Manager/ the lovelace dangled after his secretary «Зав. отделом / этотбабникухлестывалзасвоейсекретаршей».

В первом случае («зав. отделом»)акцент сделан на служебном положении человека (которым он злоупотребляет), аво втором («бабник») - на его личных 
качествах (которые он пускает в ход).

В свободном варьировании могут состоять те имена, чье смысловое различие в том или ином контекстенерелевантно. Сюда обычно относятся имена, которыесостоят в той или иной системной связи - близкой синонимии (e.g. stoker«кочегар»/ boiler-man«истопник»), тематической общности (e.g. shareholder«акционер»/ jointowner«совладелец»), гиперо-гипонимии (e.g. physician«врач» / surgeon«хирург»). В частности, человека, который водит автобус, можно обозначить не только точным названием busman «водитель автобуса», но и более общим названием driver «водитель», если вид транспорта можно установить по контексту.

Но и те имена, которые не состоят друг с другом в системной связи,в некоторых контекстах тоже могут оказаться в свободном варьировании:

Thestrip-teaser / / thegirlwrithedroundthepost «Стриптизерша/ девицаизвиваласьвокругшеста».В этом контексте имя позиционной роли (стриптизерша)и гендерно-возрастной маркер (девица) взаимозаменимы.

Говорящийинтуитивно учитывает, в каком распределении находятся имена лица, и в зависимости от этого выбирает имя. В случае свободного варьирования выбор более или менее произволен; он обусловлен разве что индивидуальными преференциями продуцента речи, а в художественном тексте - стилистическим требованием чередовать имена одного и того же лица во избежание однообразного повторения. Так, в романах Р.Стаута повествователь (Гудвин) называет своего патрона иногдапо фамилии (Wolfe),иногда - theBoss «шеф», а иногда - thegreatdetective «великийсыщик». Строго говоря, эти имена лингвопрагматически не совсем одинаковы: первое нейтрально, второе слегка фамильярно,а третье иронично. Трудно найти полные функциональные эквиваленты; однако мелкие различия зачастую оказываются не значимыми для выбораимени лица в той или иной речевой ситуации.

Добавим, что выбор имени лица по вышеописаннымправилам нередко определяется контекстом более широким, чем одно высказывание. Так, в романе 
Э.Доктороу «Ragtime», в котором фигурирует типичная американская семья, герои неизменно зовутся Mother «мама», Father «папа», theboy «сынок», Grandfather «дедушка», Mother'sYoungerBrother «мамин младший брат»независимо от того, какие действия они совершают, каковыкоммуникативные целивысказываний и их стилистические характеристики.Например:

Motherwentbackdownstairsandfoundthefellownotatthebackdoorbutinthekitchen «Мама вновь спустилась по лестнице и обнаружила, что пришелец уже не стоит у черного хода, а прошел на кухню».

Всё происходящее в романе подается автором сквозь призму жизни этой семьи. На всем протяжении романа имена родства стали постоянными именами главных героев, выступая как эквиваленты их имен собственных. Контекстом,обусловившимвыбор имен героев, служат не отдельные высказывания, а весь текст романа. Такие правилавыбора имен наиболее трудны для формализации в целях их включения в генеративную модель.

Таково, в общих чертах, влияние жанрово-стилевых характеристик дискурса на выбор имен в процессе порождения речи. 


\section{Литература}

1. Апресян Ю.Д. Лингвистические проблемы формального семантического анализа предложения // Структура текста-81: Тезисы симпозиума.М.: Наука, 1981. C. $16-20$.

2. Карасик В.И. Язык социального статуса. М. - Волгоград: Ин-т языкознания РАН, ВГПИ, 1992. $330 \mathrm{c}$.

3. Леонтьев А.А. Порождение речи // Лингвистический энциклопедический словарь. М.: Советская Энциклопедия, 1990. С. 387.

4. Поляков М.Я.Вопросы поэтики и художественной семантики. М.: Советский писатель, 1986.479 с.

5. Савицкий В.М. Порождение речи: дескриптивный подход. Самара: изд-во ПГСГА, 2013. $226 \mathrm{c.}$

6. Степанов Ю.С.Стилистика // Лингвистический энциклопедический словарь. М.: Советская Энциклопедия, 1990.С. 492-493.

7. Формановская Н.И. Речевой этикет // Советский энциклопедический словарь.М.: Советская Энциклопедия, 1990. С. 413.

8. Gleason H.A. Introduction to Descriptive Linguistics. New York: Holt, Rinehart\& Winston, $1966.503 \mathrm{p}$.

9. HallidayM. Languageas Social Semiotic. London: E.Arnold Publishers, 1978.256 p.

10.Harris Z.S. Methods in Structural Linguistics. Chicago, IL: University of Chicago Press, 1951.368 p. 